\title{
Productive and technological characteristics of goat farmers in Comondú, Baja California Sur
}

\author{
Avalos-Gastro, Raúl ${ }^{1}$; Osuna-Amador, José Denis ${ }^{1}$; Cabada-Tavares, Carlos Ariel ${ }^{1}$; \\ Medina-Górdova, Noé de Jesús ${ }^{1}$; Gadena-Iñiguez, Pedro ${ }^{2}$; Ariza-Flores, Rafael ${ }^{3}$
}

1 Instituto Nacional de Investigaciones forestales, Agrícolas y Pecuarias. Centro de Investigación Regional del Noroeste, Campo Experimental Todos Santo. Agricultura s/n, Col. Emiliano Zapata, C. P. 23070, La Paz, B. C. S., México. http://orcid.org/0000-0003-3953-1444; https://orcid.org/0000-0002-1707-6269; https:// orcid.org/0000-0003-3115-024X; https://orcid.org/0000-0001-7743-987X

2 Instituto Nacional de Investigaciones Forestales, Agrícolas y Pecuarias, México. Centro de Chiapas, Km 3, carretera Ocozocoautla-Cintalapa, Ocozocoautla de Espinosa Chiapas, CP 29140; https://orcid.org/00000002-9726-8972

3 Instituto Nacional de Investigaciones Forestales, Agrícolas y Pecuarias. Campo Experimental Valles Centrales de Oaxaca. Melchor Ocampo \# 7, Santo Domingo Barrio BAjo, Villa de Etla, Oax, 68200, México https://orcid.org/0000-0001-5764-2723

* Correspondence: cadena.pedro@inifap.gob.mx

Gitation: Avalos-Castro, R., OsunaAmador, J. D., Cabada-Tavares, C. A., Medina-Córdova, N. de J., Cadena-Iñiguez, P. \& Ariza-Flores, R. (2021). Productive and technological characteristics of goat farmers in Comondú, Baja California Sur. Agro Productividad. https://doi.org/ 10.32854/ agrop.v14i8.2132

Editor in Chief: Dr. Jorge Cadena Iñiguez

Received: March 18, 2021. Accepted: October 23, 2021. Published on-line: November 30, 2021.

This work is licensed under a Creative Commons Attribution-NonCommercial 4.0 International license.

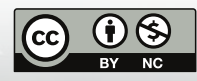

\section{ABSTRACT}

To identify productive characteristics through the technological indicators adopted by goats farmers at the Comondú municipality, state of Baja California Sur, Mexico. A survey consisting of semi-structured questions was designed to obtain multi-criteria information on the variables of technological, economic, social, and multilevel indicators. The production units (PUs) were classified by the cluster analysis of means statistical method in the SAS software, allowing to identify four groups of producers of $10.33,69,10.33$, and $10.33 \%$ of them. The social indicator demonstrated differences between UPs regard their education level, non-inclusion of women in the activity, total annual income, and whether or not they are members of an association. The technological indicator revealed differences in their distance from the UPs to the community, road conditions, area of the UP, available area for planting, water sources, herd size, availability to facilities, machinery, and equipment. The economic indicator showed differences between UPs in their agricultural complementary activities, economic dependence, milk production, cheese production, animal wastes, goat production, and their respective sales values. The conclusion is that this information is useful for particularly attending to the needs and will allow defining the precise kind of intervention in the management practices or the required management.

Keywords: goats, technology transfer, adoption.

Objective: Identify the productive characteristics through technological indicators implemented by goat farmers at the Comondú Municipality, Baja California Sur, Mexico.

Design/methodology/approach: A survey consisting of semi-structured questions was designed to obtain multi-criteria information on variables of technological, economic, social, and multilevel indicators. To determine the sample size, the formula suggested by Snedecor and Cochran (1967 and cited by Rojas, 1979); Cadena, (2004); Uzcanga et al. (2021) was used. It states that the elements must be selected by a random draw 
with replacement in the case of the producers representing each FPU, who participate in the PRODETER program, and according to the numerical characteristics of the universe of producers.

Results: The production units (PU) were classified using the cluster analysis of means statistical method with the SAS software, which allowed to identify four groups of producers with 10.33, 69, 10.33, and 10.33\% of them. The social indicator revealed differences between PUs in the degree of schooling, the non-inclusion of women in the activity, total annual income, and whether or not they are members of an association. The technological indicator found differences in the distance of the PU from the community, road conditions, area of the PU, area available for planting, water sources, herd size, availability of facilities, machinery, and equipment. The economic indicator indicated differences between the PUs in the complementary agricultural activities, economic dependence, production of milk, production of cheese, cull animals, production of goats, and their respective sales values.

Findings/conclusions: Technology indicators, herd size, and distance from the PUs to the municipal seat and community, allowed grouping and understanding the producers in a better way based on their social characteristics, technological and economic indicators. Such information will allow to precisely define the required management practices or management interventions.

\section{INTRODUCTION}

The public policy issue in the general provisions and operating guidelines of the rural development program of the Secretaria de Agricultura y Desarrollo (Secretary of Agriculture and Rural Development, Mexico) for the 2019 fiscal year (DOF-28/02/2019) and modified on 01/11/2019 indicate that the aids of the Rural Development Program are destined to small producers, located in high and very high marginated areas, applying social inclusion and gender equity criteria. Family Production Units (FPU) are a group of associated producers with a common goal, with no legal formality, or constituted as associative figures according to the national legal order. For this purpose, three parties join forces: extensionism, research, and productive sector to create synergy and for innovation management.

The Secretaria de Agricultura y Desarrollo Rural (Secretary of Agriculture and Rural Development) defined territorial development as an action where two segments converge: infrastructure investment and knowledge investment. so that farmers, producers, and ranchers (for this document, using any of the three concepts will be considered as synonymous among each other, and differentiates ranchers given the activity they develop)

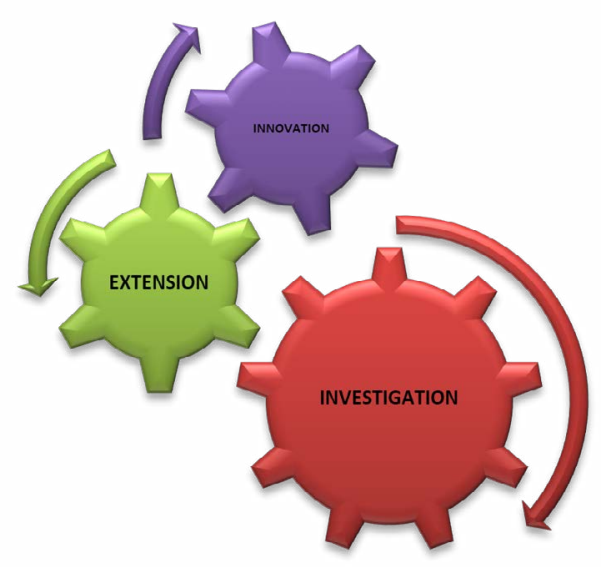

Figure 1. Elements that make up the development strategy of PRODETER. Source SADER, 2019. 
are considered subjects and not as beneficiaries and recipients of government programs that contribute to their benefit and that of their families.

In this regard, INIFAP is directly involved with the research segment, committing to three fundamental actions, based on the available technologies, providing technical support to the FPUs grouped in functional organizations to achieve or manage innovation, based on a territorial diagnosis through the characterization of the FPU, for which detected problems prioritization was carried out and a differential work model was used in the assessed territories.

The Mexican Secretaría de Agricultura (Secretary of Agriculture) identified four opportunity areas to operationalize the above graphically framed:

I. Capacity Building, Extension, and Rural Advisory Services.

II. Production Chains Economic Integration.

III. Strengthening of Family Production Units.

IV. Research and Technology Transfer. In this area, for which the Instituto Nacional de Investigaciones, Forestales, Agrícolas y Pecuarias (National Institute of Forestry, Agricultural and Livestock Research, INIFAP) is responsible, three deliverables were agreed upon:

1. Technical-productive diagnosis of the Family Production Units, which consisted of the following sections or activities:

a. Technological characterization of the Family Production Units.

b. Identification of production problems.

c. Definition and estimation of productive indicators, baseline diagnosis to contrast the annual advances of the technological intervention.

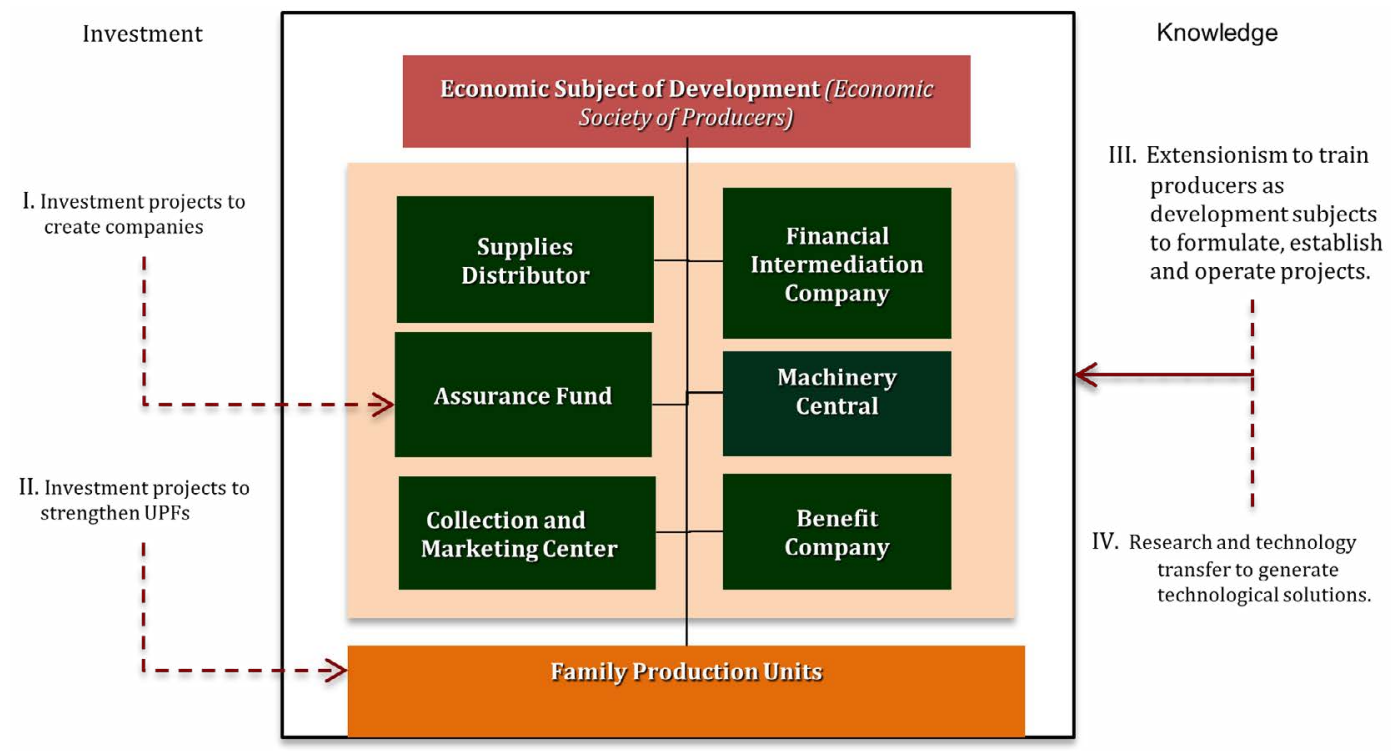

Figure 2. Areas of opportunity for development the PRODETER. Source SADER, 2019. 
d. Proposal of a technological model based on the available technologies by INIFAP or other higher education/research institutions.

\section{Technology Transfer Proposal}

a. Demonstration modules (on the producers' land) and demonstration events.

b. Execution of a program for the development of technical capacities for extensionists and producers.

c. Sessions to exchange experience and knowledge among producers.

\section{Technical Support Strategy}

The objective was to provide feedback to the producers and extensionists in applying technological components, allowing a direct interrelation between extensionists, producers, and the researcher in the field; a concept widely described by Everett Rogers (1983) in the 1960s. Who in that decade, proposed the Traditional Model of Diffusion and Adoption of Innovations. There, the author proposed that new knowledge generation through scientific research on agricultural aspects was a basic necessity, a task developed in experimental stations or fields in different conditions and circumstances than those of the producers. Once the technology was developed, it was transmitted to technicians or "change agents", so that they bridged between researchers and the producers (Axinn, 1993). Therefore, the process was one-way vertical from research to farmers. This way, the transfer was focused on scientific and technological achievements and not on the farmers. Eponou (1993) defined the model proposed by Rogers as a linear, or vertical model, where the activities are separated, without interrelation or feedback between the integrating elements, and mentioned that there is a clear labor division in each of the described stages. Researchers carry out the research, extensionists deliver the technologies and the farmers use them. Validation or testing is conducted on farmers' land; this process is oriented by the researchers, but strongly involves extensionists; the process seeks to refine the technology and test it for technical, financial, and environmental adaptation of the farmers.

During the early ' 60 s, Rogers stated that the approach was a continuous process, that started by generating innovations, followed by a validation stage, to be later extended among producers through programs led by agricultural development offices. After which, farmers are expected to adopt the innovations (Rogers, 1983), detailed concepts and discuss different situations and contexts (Cadena et al., 2018). Based on this model, technical support was carried out on producers' and ranchers' plots and/or ranches. A program with visits within the assessed territory was designed by the researchers, considering: the phenological stages of the crop, physiological stages of the animals, recommended technological components, and other specific aspects. Although it is not specifically described, the model used in the characterization of the goat farmers is closer to that by Röling in 1988, where there is an interrelation between the components, i.e., research, extension, and producers (Röling, 1988; Röling, 1990; Lionberger1986; Kaimowitz et al., 1990; Manzo, 1994; Cadena 2004). 


\section{MATERIALS AND METHODS}

A survey consisting of semi-structured questions was designed to obtain multi-criteria information of the variables of technological, economic, social, and multilevel indicators. To determine the sample size, the formula suggested by Snedecor and Cochran (1967, cited by Rojas, 1979), Cadena (2004), Uzcanga et al., 2021) was used. This indicates that the elements should be selected through a random draw with replacement in the case of those producers representing each FPU, participating in the PRODETER program and according to the numerical characteristics of the universe of producers. To accomplish this, the lists of producers provided by each promoter or extensionist were used, the producers were then selected from the universe in each of the strategies following the formula:

$$
n=\frac{\frac{Z^{2} p_{n} q}{d^{2}}}{1+\frac{Z^{2} p_{n} q}{N d^{2}}}
$$

The mathematical equation details as follows based on a hypothetical universe: Where: $Z=$ Confidence Level, $D=$ Precision level, $p_{n}=$ Proportion of the population from to the group of interest $q=(1-\mathrm{pn}), N=$ Population size, $N=$ Sample size.

A questionnaire that was personally applied to $14.5 \%$ of the producers ( $\mathrm{n}=29$ surveys) was designed considering a simple random sampling and taking as a basis the list of participants in the PRODETER program $(\mathrm{N}=200)$; semi-structured interviews were applied to the producers to obtain multi-criteria information on several variables of the technological, economic, social and multilevel indicators.

The information from the semi-structured interviews at the production unit was systematized in a database in Excel software. To classify the production units (PU), the technological development index proposed by Nahed et al. (2021) was used. The indicators which comprise it were infrastructure possession, machinery, and equipment (grade), which made up thirteen variables (Table 1), and management practices application (grade) made up of ten variables (Table 2). Tables 1 and 2 show the indicators, their variables, and the evaluated characteristics to obtain the technological development indexes. Each indicator's value is the average of the scores of its component variables.

The PUs were classified using the cluster analysis statistical method for means, for which the herd size and distance from the PUs technological development indexes were used as grouping variables. The multivariate statistical method of cluster analysis, groups homogeneous intra-group data (minimum variance) allows to differentiate heterogeneous inter-group data (maximum variance) and generates a vector of PU membership in the clusters.

Subsequently, the clusters or groups of PUs identified were characterized by the variables of the social, technological, and economic indicators. The social indicator variables were: age of the producers (years), women's inclusion in the activity (\%), educational level of the 
Table 1. Evaluated variables and characteristics used to elaborate the identification of technological indicators regard the possession of facilities, machinery and equipment (grade). INIFAP, 2021.

\begin{tabular}{l|c|ll}
\hline \multicolumn{1}{c|}{ Variable } & Feature & \multicolumn{2}{c}{ Scoring criteria } \\
\hline Corral & Own & yes $=1 \quad$ No $=0$ \\
\hline Milking room & Own & yes $=1$ & No $=0$ \\
\hline Drinking fountain & Own & yes $=1$ & No=0 \\
\hline Eatable & Own & yes $=1$ & No $=0$ \\
\hline Wine cellar & Own & yes $=1$ & No=0 \\
\hline Dairy workshop & Own & yes $=1$ & No=0 \\
\hline Plough & Own & yes $=1$ & No=0 \\
\hline Tractor & Own & yes $=1$ & No=0 \\
\hline Drag & Own & yes $=1$ & No=0 \\
\hline Water pump & Own & yes $=1$ & No=0 \\
\hline Scale & Own & yes $=1$ & No=0 \\
\hline Rennet tubs & Own & yes $=1$ & No=0 \\
\hline Pickup truck & Own & yes $=1$ & No=0 \\
\hline
\end{tabular}

Table 2. Evaluated variables and characteristics to elaborate the identification of technological indicators regard management practices (grade). INIFAP, 2021.

\begin{tabular}{|c|c|c|c|}
\hline Variable & Feature & \multicolumn{2}{|c|}{ Sciring criteria } \\
\hline \multirow{4}{*}{ Records management } & Aretado & Yes $=1$ & $\mathrm{No}_{\mathrm{O}}=0$ \\
\hline & Lotifica herd & Yes $=1$ & $\mathrm{No}_{\mathrm{O}}=0$ \\
\hline & Productive records & Yes $=1$ & $\mathrm{No}=0$ \\
\hline & Qualification & \multicolumn{2}{|c|}{ Maximum Summation $=3$} \\
\hline \multirow{8}{*}{ Zootechnical management } & Ensures colostrum consumption & Yes $=1$ & $\mathrm{No}=0$ \\
\hline & Use evaluated players & Yes $=1$ & $\mathrm{No}=0$ \\
\hline & Supplement stallions & Yes $=1$ & $\mathrm{No}=0$ \\
\hline & Supplement females & Yes $=1$ & $\mathrm{No}=0$ \\
\hline & Deworming & Yes $=1$ & $\mathrm{No}=0$ \\
\hline & Perform mastitis tests & Yes $=1$ & $\mathrm{No}_{\mathrm{O}}=0$ \\
\hline & Adjust animal load & Yes $=1$ & $\mathrm{No}=0$ \\
\hline & Qualification & \multicolumn{2}{|c|}{ Maximum Summation $=7$} \\
\hline
\end{tabular}

producer (none, elementary, secondary, high school or bachelor's degree), family members working on the ranch (number), total annual income including cheese sales, cull animals, capons and goal kids (\$), type of owned property (private, ejido, communal or rented) and whether they are part of an association (\%); the technological indicator variables were: distance from the PU to the municipality head or to the community $(\mathrm{km})$, percentage of producers with good, regular or bad road conditions, area of the PU (ha), planted available area (ha), availability (\%) of water for the livestock (stream, dam, spring, well 
or jar), percentage of producers by production system (semi - stabled or extensive), herd size (head), breed diversity (number), breeding females (head), sires (head), birth rate (\%), abortions (\%), availability of the facilities (grade), machinery and equipment availability (grade), record keeping (grade) and husbandry practices application (grade); the economic indicator variables were: complementary activities (agricultural and livestock), PU income from goat farming ( $<50$, between 50-99 and 100\%), average milk production $(\mathrm{L})$, cheese production $(\mathrm{kg})$, cheese sales value (\$), cull animal sale (heads), cull animal sale value (\$), capon sale (heads), capon sale value (\$), cabrito sale (heads), goat kids sale value (\$), goat kids sale (heads), and sale value per goat kid (\$).

Statistical analyses were performed with the SAS statistical software (2014).

\section{RESULTS AND DISCUSSION}

Production units' classification. The cluster analysis allowed to identify four groups of producers. Clusters 1, 2, 3, and 4 grouped 10.33, 69, 10.33, and 10.33\% of them, respectively.

Social characterization of the production units based on technological indexes. Table 3 presents the variables for the social indicator. The main observed difference was recorded in the educational level, the non-inclusion of women in the activity, the highest total annual income, and being part of an association; these last three among cluster 4 producers, while the cluster 3 producers had a lower educational level. Producers in cluster 2 were more diverse regard their education level and the type of property they owned.

Technological characterization of the production units based on technological indexes. Table 4 shows the variables of the technological indicator. The cluster 1 producers present the shortest distance from the community, larger production unit area, birth rate, facilities availability, planting area, and a greater degree of record keeping. Producers in cluster 2

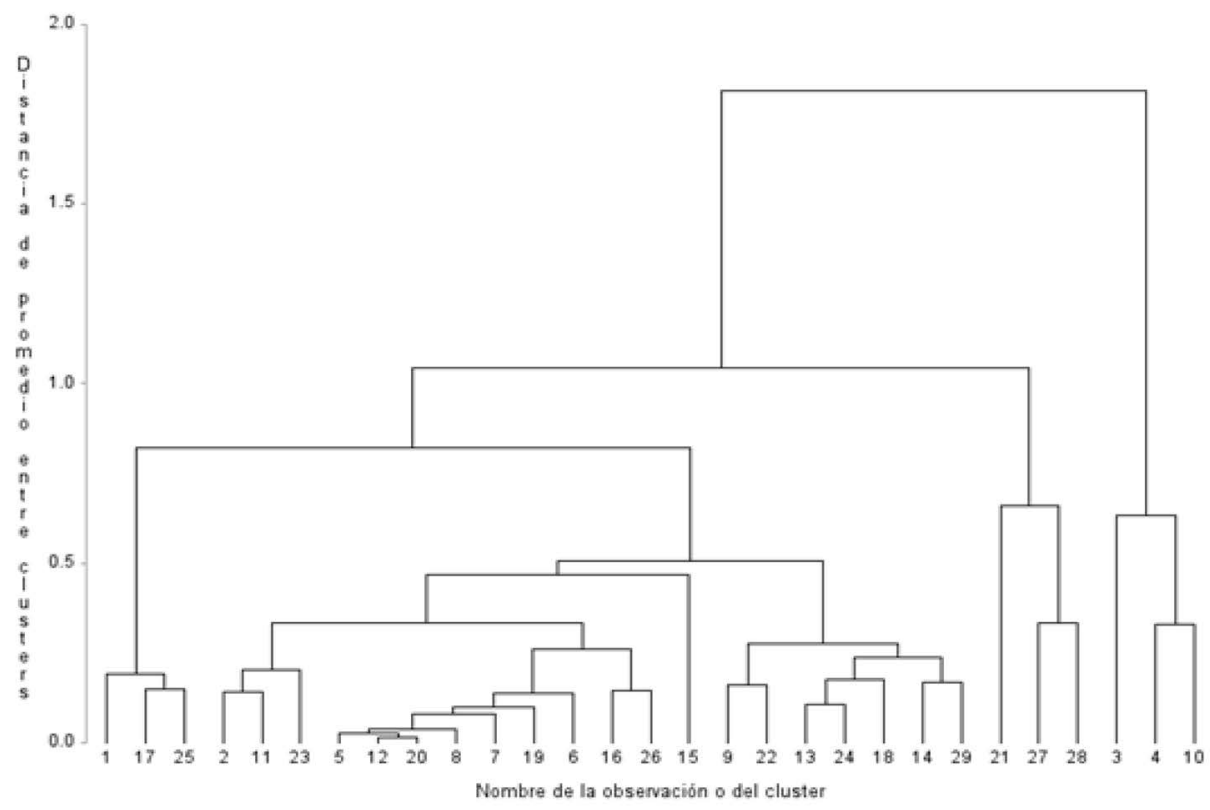

Figure 3. Number of integrated clusters according to the adopted technologies. INIFAP, 2021. 
Table 3. Variables of the social indicator. INIFAP, 2021.

\begin{tabular}{|c|c|c|c|c|}
\hline Variable & $\begin{array}{c}\text { Conglomerate } \\
1 \\
\end{array}$ & $\begin{array}{c}\text { Conglomerate } \\
2 \\
\end{array}$ & $\begin{array}{c}\text { Conglomerate } \\
3 \\
\end{array}$ & $\begin{array}{c}\text { Conglomerate } \\
4 \\
\end{array}$ \\
\hline Production units & 3 & 20 & 3 & 3 \\
\hline Age (years) & 49.6 & 50 & 53 & 46 \\
\hline \multicolumn{5}{|l|}{ Schooling (\%) } \\
\hline Primary & 0 & 30 & 100 & 67 \\
\hline High school & 100 & 30 & 0 & 33 \\
\hline High school & 0 & 20 & 0 & 0 \\
\hline Degree & 0 & 10 & 0 & 0 \\
\hline No & 0 & 10 & 0 & 0 \\
\hline Family members working on the ranch (number) & 3.3 & 2.3 & 2.3 & 3 \\
\hline Inclusion of women (\%) & 33 & 35 & 33 & 0 \\
\hline Total income $(\$ /$ year $)$ & 126967 & 52134.7 & 31200 & 141033 \\
\hline \multicolumn{5}{|l|}{ Type of ownership (\% of producers) } \\
\hline Private & 67 & 30 & 67 & 33 \\
\hline Ejidal & 33 & 60 & 33 & 67 \\
\hline Communal & 0 & 5 & 0 & 0 \\
\hline Rented & 0 & 5 & 0 & 0 \\
\hline Be part of an association (\%) & 67 & 85 & 67 & 100 \\
\hline
\end{tabular}

reported the shortest distance from the municipality, better road conditions, more water source diversity for the livestock, semi-stabled production systems, most diverse breeds, and the lowest number of breeding and milking goats. The third cluster grouped producers with the longest distance to the community, water availability from dams and springs, high abortion rates, lowest facilities availability, and highest equipment and machinery availability. Cluster 4 groups the producers with the greatest distance to the municipality, worst road conditions, smallest PU area, no available planting surface, available water for cattle from streams, extensive production system, largest herd size, smaller diversity of breeds, a higher number of breeding and milking females, more stallions and the lowest abortion percentage.

Zootechnical management practices (degree) are similar among producers in the different clusters.

Economic characterization of the production units based on technological indexes. Table 5 shows the variables of the economic indicator. The producers in cluster 1 have the highest percentage of complementary activities, the highest milk production, cheese, castrated animals, and the higher income from the sale of cheese and capons. Producers in cluster 2 have a higher dependence on the goat activity and a lower animals disposal rate. Cluster 3 groups producers with the lowest milk production, the lowest income from cheese sales, and with no castrated animals or got kids production from sales. Producers in cluster 4 are exclusively dedicated to complementary livestock activities, have the highest number of castrated animals and goat kids, so the highest income is obtained from these activities. 
Table 4. Variables of the technological indicator. INIFAP, 2021.

\begin{tabular}{|c|c|c|c|c|}
\hline Variable & $\begin{array}{c}\text { Conglomerate } \\
1\end{array}$ & $\begin{array}{c}\text { Conglomerate } \\
2 \\
\end{array}$ & $\begin{array}{c}\text { Conglomerate } \\
3 \\
\end{array}$ & $\begin{array}{c}\text { Conglomerate } \\
4 \\
\end{array}$ \\
\hline Production units & 3 & 20 & 3 & 3 \\
\hline \multicolumn{5}{|l|}{ Distance from production unit $(\mathrm{km})$} \\
\hline Municipal seat & 168 & 159 & 162 & 192 \\
\hline Community & 23 & 29 & 199 & 39 \\
\hline \multicolumn{5}{|l|}{ Road conditions (\%) } \\
\hline Well & 0 & 5 & 0 & 0 \\
\hline Regular & 33 & 35 & 33 & 0 \\
\hline Bad boy & 67 & 60 & 67 & 100 \\
\hline Surface of the UP (ha) & 1300 & 448 & 1292 & 53.5 \\
\hline Area available for sowing (ha) & 1.5 & 0.24 & 0.66 & 0 \\
\hline \multicolumn{5}{|l|}{ Water sources for livestock (\%) } \\
\hline Brook & 100 & 65 & 0 & 100 \\
\hline Dams & 0 & 10 & 67 & 0 \\
\hline Spring & 0 & 5 & 33 & 0 \\
\hline Well & 0 & 10 & 0 & 0 \\
\hline Jars & 0 & 10 & 0 & 0 \\
\hline \multicolumn{5}{|l|}{ Production system } \\
\hline Semi - stabled & 0 & 25 & 0 & 0 \\
\hline Extensive & 100 & 75 & 100 & 100 \\
\hline Herd size (heads) & 255 & 113 & 145 & 453 \\
\hline Diversity of breeds (number) & 5 & 7 & 5 & 4 \\
\hline Breeding females (heads) & 133 & 56 & 66 & 240 \\
\hline Females in milking (heads) & 73 & 32 & 46 & 177 \\
\hline Stallions (heads) & 3.3 & 2.5 & 3.3 & 6 \\
\hline Birth rate $(\%)$ & 100 & 80 & 67 & 67 \\
\hline Abortions $(\%)$ & 20 & 19 & 28 & 10 \\
\hline Availability of facilities (grade) & 0.38 & 0.24 & 0.11 & 0.16 \\
\hline $\begin{array}{l}\text { Availability of machinery and } \\
\text { equipment (grade) }\end{array}$ & 0.19 & 0.12 & 0.24 & 0.14 \\
\hline Records management (grade) & 2 & 1.45 & 1.67 & 1.33 \\
\hline Zootechnical management (degree) & 3.3 & 2.95 & 3.4 & 3 \\
\hline
\end{tabular}

\section{Nubian and Saanen breeds are the most used in the PUs. Only producers in clusters 1 and 2 use Creole goats. The Boer breed is utilized by producers in clusters 2 and 4}

Comondú goat farmers milk an average of four of the six milk production months, calves are nursed for two months, during this time some goat farmers also alternate with minimal milking. In this sense, the estimated milk production for the group of producers in cluster 1 was 164 liters per goat per year or 1.3 liters per goat per day. For this variable, the estimated milk production would be $1.14,0.26$, and 0.43 liters per goat per day for 
Table 5. Variables of the economic indicators. INIFAP, 2021.

\begin{tabular}{|c|c|c|c|c|}
\hline Variable & $\begin{array}{c}\text { Conglomerate } \\
1 \\
\end{array}$ & $\begin{array}{c}\text { Conglomerate } \\
2 \\
\end{array}$ & $\begin{array}{c}\text { Conglomerate } \\
3 \\
\end{array}$ & $\begin{array}{c}\text { Conglomerate } \\
4 \\
\end{array}$ \\
\hline Production units & 3 & 20 & 3 & 3 \\
\hline \multicolumn{5}{|l|}{ Complementary activities } \\
\hline Agricultural & 100 & 25 & 33 & 0 \\
\hline Livestock & 100 & 95 & 100 & 100 \\
\hline \multicolumn{5}{|c|}{ Admission to the UP for goat farming (\%) } \\
\hline$<50$ & 33 & 10 & 0 & 0 \\
\hline $50-99$ & 0 & 5 & 33 & 33 \\
\hline 100 & 67 & 85 & 67 & 67 \\
\hline Milk production $(\mathrm{L})$ & 12000 & 4360 & 1433 & 9040 \\
\hline Cheese production $(\mathrm{kg})$ & 1520 & 734.8 & 400 & 1383 \\
\hline Sale value of cheese $(\$)$ & 77600 & 37399.7 & 20000 & 73700 \\
\hline Waste animals (heads) & 20 & 6 & 10 & 33 \\
\hline Sale value of waste animals $(\$)$ & 23200 & 6450 & 11200 & 37333 \\
\hline Capons (heads) & 17 & 5 & 0 & 5 \\
\hline Sale value of capons $(\$)$ & 19600 & 5005 & 0 & 5000 \\
\hline Production of goats (heads) & 13 & 7 & 0 & 50 \\
\hline Sale value of goats $(\$)$ & 6667 & 3280 & 0 & 25000 \\
\hline
\end{tabular}

producers in clusters 2, 3, and 4, respectively. Cluster 1 producers have the highest birth percentage, facilities availability, land availability for sowing, and a higher discard of unproductive or cull animals (8\%), have higher milk production, and consequently the highest cheese production. The reduced distance from the community could also be an advantage to commercialize their products compared to the rest of the PUs. The cluster 2 PUs have similar characteristics to those of cluster 1 PUs, their main difference lies in the number of producers that practice the semi-stabled production system, the number of animals they own, the ranch surface, and that the higher income of the PU depends on the goat's activity and have better road conditions. Both clusters of the producers ( 1 and 2 ), in contrast to the other two, employ Creole animals, which in the local climatic and topographic conditions have a longer adaptation period than the rest of the introduced breeds of the herds in the state, this adaptive advantage, with the crossbreeding of other breeds, can also be the result of higher milk production.

Based on the technological and economic indicators, the producers grouped in cluster 3 are the ones with the greatest productive lag. Probably because of their lower educational degree and lower facilities availability, although they have the highest equipment and machinery availability, as well as water from dams and springs and planting area. This is not reflected, probably due to the lack of technical support in the efficient usage of these resources. Another important factor that may affect this situation is the distance they have to travel to their community for education or products commercialization. Therefore, it is assumed that the production of goats and goat kids is for self-consumption. 
Table 6. Distribution (\%) of the main breeds used by production unit. INIFAP, 2021.

\begin{tabular}{l|c|c|c|c}
\hline \multicolumn{1}{c|}{ Variable } & Conglomerate & Conglomerate & Conglomerate & Conglomerate \\
& $\mathbf{1}$ & $\mathbf{2}$ & $\mathbf{3}$ & 3 \\
\hline Production units & 3 & 20 & 67 & 33 \\
\hline Alpine & 33 & 20 & 100 & 33 \\
\hline Saanen & 67 & 25 & 67 & 0 \\
\hline Toggenburg & 0 & 10 & 67 & 100 \\
\hline Nubia & 100 & 100 & 0 & 33 \\
\hline Boer & 0 & 25 & 33 & 0 \\
\hline Murcia & 33 & 15 & 0 & 0 \\
\hline Creole & 33 & 40 & & 33 \\
\hline
\end{tabular}

Producers in cluster 4, who have the highest annual income, have a low milk yield per goat per day $(0.43 \mathrm{~L})$. Therefore, the income reflects the higher number of animals and not of their efficiency. Additionally, using Boer breed animals is efficient for meat production, but inefficient to produce milk. If animals born of these breeds are left as breeding stock, there is a risk that they develop accessory mammary glands, resulting in a greater efficiency loss in the milk production process.

As for the variables of the indexes of technological development in the PUs, in all the assessed groups, low adoption of technologies was observed, ranging from 11 to 38\% for the facilities available, from 12 to $24 \%$ in the machinery and equipment availability, management of records degree ranging from 1.33 to 2, based on a 3 grading, and in the implementation of zootechnical practices from 2.9 to 3.4 based on a maximum implementation grade out of 7 . This last one is the most important in the productive efficiency of the PUs.

Although this overview of the characteristics of the producers regard their technological levels, allow to identify different groups of goat farmers and the destination they give to their primary products, and offers opportunity areas for them to be educated in agribusiness or provide added value to the milk. So that, in addition to the milk production period, they offer feeding schemes that allow to increase slightly more period or use specialized breeds to increase production or sale calves to demanding markets (Cadena et al., 2019).

The grouping considers the information and offers the possibility of prioritizing the research of the PUs according to their limitations, potentialities, and opportunities, improving the decision-making process (Falconi and Burbano, 2004; Munda, 2004) for planning and developing the public policy on the livestock of the region or state.

\section{GONGLUSIONS}

The technological indexes, herd size, and distance from the PUs to the municipality and the community allowed to group and understand the assessed producers, based on their social characteristics, technological and economic indicators. This information will make it possible to precisely define the kind of intervention required, in terms of the management practices. 


\section{REFERENCES}

Axinn, G.H. (1993). Guía de los Distintos Enfoques de la Extensión. Organización de las Naciones Unidas para la Agricultura y la Alimentación. Roma, Italia. p 51

Cadena-Iñiguez, P. (2004). Actores, estrategias y dinámicas de organización en el agro de La Frailesca, Chiapas. Tesis Doctorado en Ciencias. Programa de Estudios del Desarrollo Rural. Colegio de Postgraduados. Montecillo, Estado de México. 154 p.

Cadena-Iñiguez, P., Guevara-Hernández, F., Argüello-Aguilar, R.A., Rendón-Medel, R. (2018). Proceso de comunicación, extensionismo y adopción de tecnologías. Revista Mexicana de Ciencias Agrícolas. 9 (4). 851-862.

Cadena-Iñiguez, P., Rodríguez-Hernández, R., Morales-Guerra, M., Berdugo-Rejón, J.G., Salinas-Cruz, E., Camas-Gómez, R., Guevara-Hernández, F., Pinto-Ruíz, R. (2019). Model of Management for Innovation in Small Farmers of Latin America; A Successful Proposal. International Journal of Agricultural Sciences and Natural Resources. 2019. 6(1). 1-7. 2375-3773

Eponou, T. (1993). Partners in Agricultural Technology: Linking Research and Technology Transfers to serve farmers. ISNAR. Research Report No 1 . The Hague: International Service for National Agricultural Research. The Netherlands. 85 p.

Falconi, F., Burbano, R. (2004). Economic tools for environmental management: mono-criteria vs. multicriteria decisions. REVIBEC. 1. 11-20.

Kaimowitz, D., Snyder, M., Engel, P. (1990). A conceptual Framework for studying the links between Agricultural Research and Technology Transfer in developing countries. In: Kaimowitz, D. (Ed), making the link: Agricultural Research and Technology Transfer in developing countries. Boulder, Colorado; Westview Press.

Lionberger, H.F. (1986). Toward and Idealized System Model for Generating and Utilizating Information in modernizing Societies. In: Beal, G., Dissanayake, W, \& Konoshima, S. (Eds). Knowledge generation, exchange and utilization. Boulder, Colorado; Westview Press.

Manzo, R.F. (1994). The Role of education and Technological Change in Rural Development. Ph. D. Thesis. North Caroline State University. USA.

Munda, G. (2004). Multicriteria methods and multicriteria processes for social evaluation of public policy. REVIBEC. 1. 31-45.

Nahed, T.J., Palma, G.J.M., Aguilar, J.J.R., Grande, G.D., Valdivieso, P.I.A., Juárez, M.H.A., Trujillo, V.R., Sánchez, M.B., Ruíz, R.J.L., León, M.N.S., Parra, V.M.R. (2021). Índice de desarrollo tecnológico para la clasificación y análisis multicriterio de unidades de producción: Aplicación en la ganadería bovina de doble propósito convencional versus orgánica. AIA. 25(2). 97-118.

Rogers, M.E. (1983). Diffusion of innovations. Third Edition. Nueva York: The Free Press. 134-149.

Rojas-Soriano, R. (1979). Guía para realizar investigaciones sociales. Facultad de Ciencias Políticas y Sociales. Universidad Autónoma de México. México, D.F. 271 p.

Röling, N. (1988). Extension Science; Information systems in agricultural development. Cambridge University Press. Reprinted 1990. Great Britain. 233 p.

Röling, N. 1990. The Agricultural Research-Technology Transfer Interface: A Knowledge System Perspective: Kaimowitz, D. 1990. Making the Link: Agriculture Research and Technology Transfer in Developing Countries. ISNAR. West View Press. USA p 1-42

SAS. 2014. SAS- Statistical Analisis Softwer for Windows ver. 9.3. Cary, NC: SAS Institute Inc.

Uzcanga-Pérez, N; Cano-González, A.; Cadena-Iñiguez, P. 2021. Strategy to strengthen the traditional milpa family production systems. ISSN 2594-0252 Agroproductividad: Vol. 14, Núm. 4, abril. 2021. Pp: 119125. 